\title{
Identification of Plasmodium species from outdated blood samples by nested-PCR compared with microscopy diagnosis in Jazan region, Saudi Arabia
}

\author{
0. M. Dafalla', A. A. Alsheikh', Abakar A. D. ${ }^{2}$, W. S. Mohammed ${ }^{1}$, Bakri Y. M.Nour ${ }^{3}$, \\ Shrwani K. J' and E. M. Noureldin*1 \\ ${ }^{1}$ National Center for Vector-Borne Diseases, MoH-Jazan, Saudi Arabia \\ ${ }^{2}$ Department of Medical Parasitology, Faculty of Medical Laboratory Sciences, University of Gezira, Sudan \\ ${ }^{3}$ Department of Parasitology, Blue Nile National Institute for Communicable Diseases, University of Gezira, Sudan
}

\begin{abstract}
Precise diagnosis of plasmodium species is essential for accurate and prompt malaria control and elimination. The present study was conducted to assess the efficiency of malaria parasites' diagnosis by microscopy and nested-PCR techniques in Jazan region. Eight hundred eighty four samples were collected from hospitals and malaria control centers of the eleven Governates of Jazan region to confirm their microscopy diagnosis for Plasmodium species. One hundred thirty eight (15.6\%) samples were randomly selected from the saved positive microscopy confirmed samples. The samples were re-diagnosed by microscopy for plasmodium species and found positive for two plasmodium species (128 for P. falciparum [92.8\%] and 10 for P. vivax [7.2\%]). But no other plasmodium species or mixed-infections were detected. On other hand, the diagnosis by nested-PCR indicated 119 (86.23\%) and 6 (4.35\%) mono infection by $P$. falciparum and $P$. vivax, respectively. In addition, the method detected also 13 (9.42\%) mixed-infections with both $P$. falciparum and $P$. vivax. Considerable numbers of species mismatch and under-reporting of mixed infections had been noticed in the diagnosis of malaria by microscopy alone in Jazan region. The nested-PCR is valuable technique as a confirmatory test and should be considered by reference laboratories in the region and other malaria endemic regions of the Kingdom of Saudi Arabia.
\end{abstract}

KEY WORDS: MALARIA, JAZAN, SAUDI ARABIA, PLASMODIUM SPECIES, MICROSCOPY, NESTED-PCR

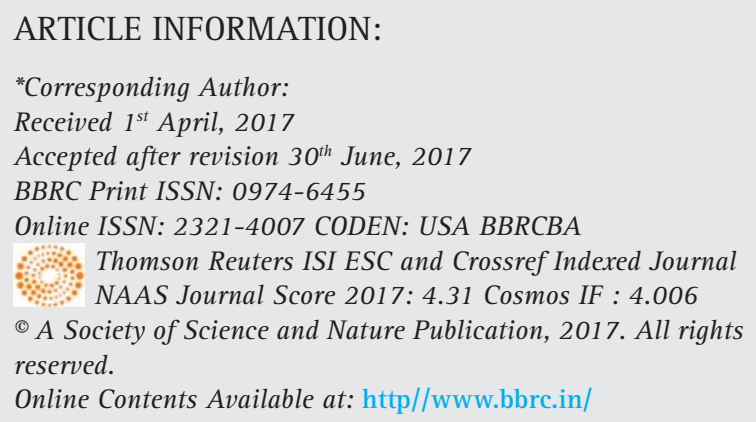




\section{INTRODUCTION}

Malaria is considered one of the most life-threatening pathogens capable of infecting human communities. Malaria infection is caused by parasites belonging to the genus Plasmodium. More than 100 species of Plasmodium have been identified and five species are capable of infecting humans; these species are Plasmodium vivax (the most widely spread parasite in the world), Plasmodium falciparum (a fatal malaria parasite causing a high mortality rate, $~ 90 \%)$, Plasmodium malariae, Plasmodium ovale and Plasmodium knowlesi (a newly discovered malaria-causing parasite). Transmission of the infectious agent is caused by the bite of female Anopheles mosquitoes, which is the vector of this parasite (Cowman and Crabb, 2006). Around fifteen Anopheles species are found in Saudi Arabia and four species are recognized as malaria vectors; these vectors are Anopheles gambiae (arabiensis), Anopheles Superpictus, Anopheles stephensi, and Anopheles sergentii (Sebai, 1988; Zahar, 1985 and CDC, 2016).

Recent figures suggest that approximately 3.2 billion people are at risk of malaria transmission due to several reasons, including immigration, international travel, poverty, lack of health system infrastructure, wars and emergence of multi-drug resistance. (Cowman and Crabb, 2006; Sebai, 1988; WHO, 2014; Askling et al., 2005). Because of proactive international health programs for combating malaria, the mortality rates have gradually decreased to around 438,000 deaths in 2015 (WHO, 2016).

According to the WHO, Saudi Arabia is known as a malaria epidemic country with around 5\% of the population at risk of transmission malaria (about 2.4 million people), particularly in its South Western regions of Tihama area, where more than 50\% of all malaria cases in the country are reported. This is mostly related to travel and immigration with reports suggesting that from 2000 to 2014, more than 5500 of diagnosed malaria cases were local compared to over 9900 imported cases. Plasmodium falciparum causes over $90 \%$ of the malaria cases in the coastal plains along the Red Sea in southern and southwestern parts of the Kingdom of Saudi Arabia (Tihama) .Plasmodium vivax is the predominant species in the northwest regions; whereas Plasmodium malariae is scarce. There is still transmission in all the southwestern regions of the country, except for the high altitude regions along the Yemen border in the Assir region. The main transmission season of malaria occurs between October and April and coincides with the rainy season (Al-Sheik, 2011, El-Hassan et al., 2015, Moke et al., 2015).

Accurate and sensitive laboratory diagnosis of malaria is essential for assessing disease severity and prescribing adequate therapy. For the last 100 years, microscopic examination and identification of Plasmodium species in thin and thick blood smears using Giemsa-stain have been considered the gold standard for malaria detection (Perandin et al., 2004). However, several drawbacks were documented in using microscopic examination, including time-consuming sample preparation, misdiagnosis of Plasmodium species due to lack of experience by operators, the complexity of examining mixed infection samples and poor sensitivity, especially with low infectious agent numbers (Johnston et al., 2006; Mangold et al., 2005; McNamara et al., 2004). Additionally, immunoassays based on antigen detection also suffer from several disadvantages leading to false results in cases of antigemia and malaria parasiteima (Mangold et al., 2005).

Polymerase chain reactions (PCR) based molecular detection can be used for the diagnosis of Plasmodium species. This technique has several advantages compared to microscopic examination or immune-assay detection, including speed, high sensitivity, excellent specificity, and very efficient species discrimination (Mangold et al., 2005; Hanscheid, 2003; Jerrard et al., 2002; Morassin et al., 2002; Patsoula et al., 2003). Conventional PCR and real-time PCR methods have the ability to differentiate the mixed infections of Plasmodium species and to detect low levels of parasite copies (Mangold et al., 2005; Lee et al., 2002). A nested-PCR technique based on S18 small subunit ribosomal DNA (rDNA) can detect levels as low as five parasite units per micro-liter of blood (Van Hong et al., 2013). Consequently, PCR is a reliable method of detection and can at least be used as a valuable confirmatory technique (Johnston et al., 2006).

In Jazan region, very few studies have been published to demonstrate the incidence of malaria with mixed- plasmodium species infections using nestedPCR and compare it with microscopically confirmed cases of malaria. However, Bin Dajem (2015) reported $1.9 \%$ malaria mixed infection cases in the region using nested-PCR. The aim of this study is to confirm the sensitivity of nested-PCR in diagnosis of Plasmodium species in outdated blood samples inappropriate for microscopy diagnosis, and to indicate the geographical distribution of Plasmodium species and comparing the finding of nested PCR with the previous result of golden standard microscopic examination, in addition to, proving the existence of mixed infection in Jazan region.

\section{MATERIALS AND METHODS}

\section{STUDY SITE}

This study carried out at eleven Governates (Al-Aridah, Damad, Twal, Al-Ahad, Jazan Al-Khobah, Samt- 


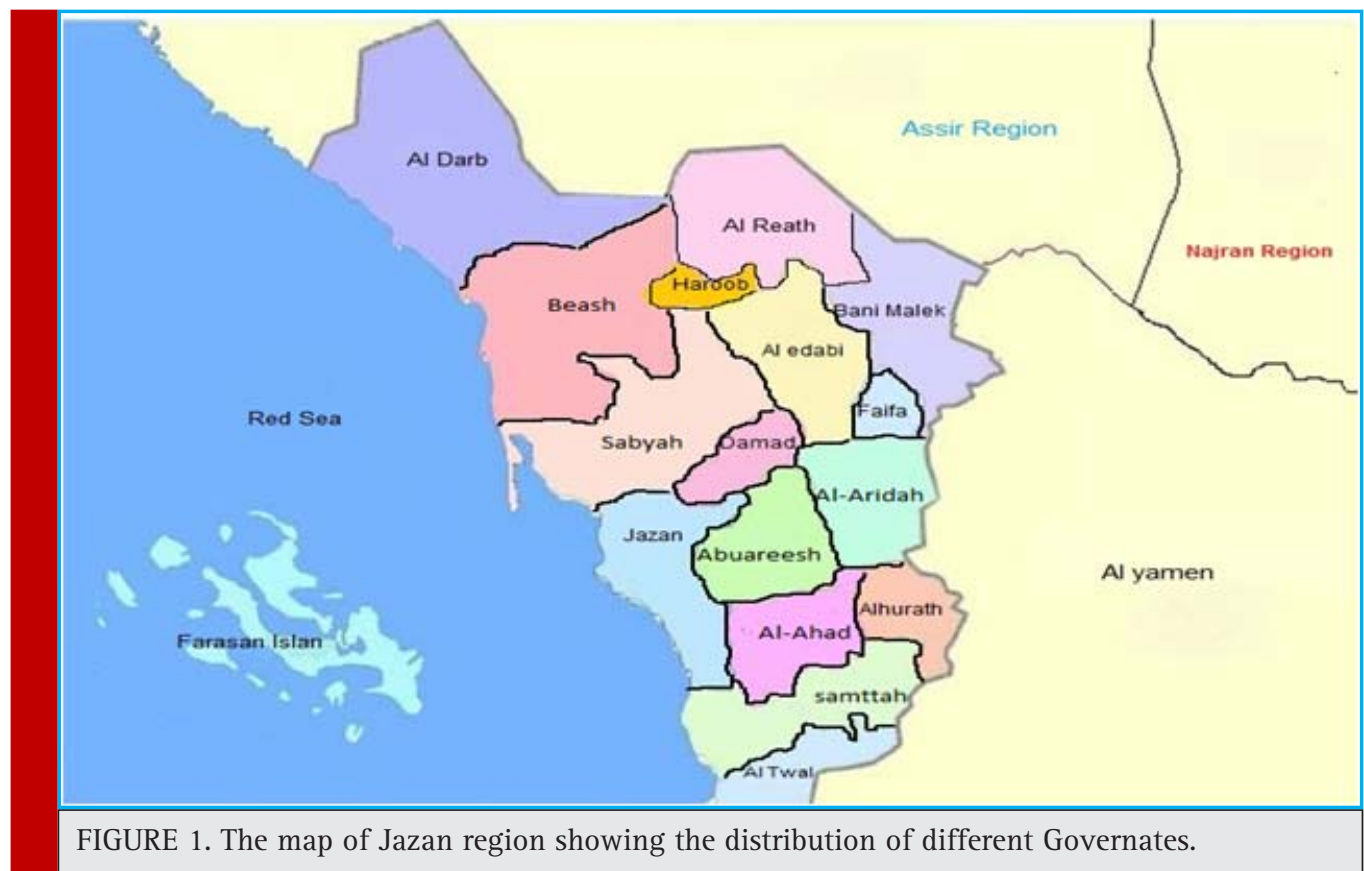

tah, Abuareesh, Sabyah, Beash and Al-Darb) in Jazan Region in Southwest Saudi Arabia, lies between $16^{\circ}-12$, and $18^{\circ}-25$, latitude north. The total area of the region is about 22,000 km², with 1.3 million populations (Census 2011). Thirty percent of the population concentrated in six major cities, and the remainders living in over 3500 villages (Al-Sheik, 2011). Jazan region is situated in the subtropical zone and has average monthly temperatures ranging from $25.8^{\circ} \mathrm{C}$ in January to $33.4^{\circ} \mathrm{C}$ in July. The average relative humidity ranges between 55\% and $72.5 \%$. The rainy season is started at August through October with a monthly average of 77 and $56.7 \mathrm{~mm}$, respectively (Al-Sheik, 2011).

These eleven locations (Fig.1) although with different altitudes and geographical Characteristics, they almost share the same demographical, agricultural, educational, cultural, housing, health system, and environmental characteristics.

\section{SAMPLES SIZE AND COLLECTION}

During 2011-2012 the National Center for Vector Borne Diseases received about 884 samples from the hospitals and malaria control centers of the eleven Governates to confirm their microscopy diagnosis for Plasmodium. This research was carried out at the beginning of 2016. One hundred thirty eight (15.6\%) samples were randomly selected from the saved positive microscopy confirmed samples. These samples were divided into four groups based on the geographical locations as shown in Table (1) bellow:

\begin{tabular}{|l|l|}
\hline \multicolumn{2}{|l|}{ Table 1. Governates area groups } \\
\hline Group No & Governorate \\
\hline Group 1 (Jazan City) & Jazan \\
\hline Group 2 (North Jazan) & Sabyah, Beash and AL-Darb \\
\hline Group 3 (South Jazan) & $\begin{array}{l}\text { Samttah, AL-Ahad, Twal and } \\
\text { Khobah }\end{array}$ \\
\hline Group 4 (East Jazan) & $\begin{array}{l}\text { Abuareesh, Damad and } \\
\text { AL-Aridah }\end{array}$ \\
\hline
\end{tabular}

\section{DNA EXTRACTION}

DNA was extracted from the stored microscopy confirmed plasmodium human blood using Wizard genomic DNA Extraction kit (Promega, U.S.A) following the manufacture's recommendations: $300 \mu$ of human blood added to $900 \mu \mathrm{l}$ of cell lysis solution in 1.5 tubes and incubate the mixture for ten minutes at room temperature (invert 2-3 times once during the incubation). Then centrifuged at $13000 \mathrm{rpm}$ for 20 seconds at room temperature then the supernatant discarded and the pellet was resuspended by vortex for 15 seconds and 300 $\mu \mathrm{l}$ of Nuclei Lysis Solution added to resuspended cells, then $100 \mu \mathrm{l}$ of Protein Precipitation was added. The mixture was purified by centrifugation at $13000 \mathrm{rpm}$ for 3 minutes and the supernatant transferred to a clean $1.5 \mathrm{ml}$ tube containing $300 \mu \mathrm{l}$ of isopropanol and mixed gently. The DNA was pelleted at $13000 \mathrm{rpm}$ for 1 minute and washed by ethanol twice and dried for 5-10 minutes at room temperature. DNA Rehydration solution used to 


\begin{tabular}{|c|c|c|c|c|}
\hline SPECIES & $\begin{array}{l}\text { PRIMER } \\
\text { NAME }\end{array}$ & SEQUENCE (5-3) & $\begin{array}{l}\text { PCR } \\
\text { PRODUCT } \\
\text { SIZE (bp) }\end{array}$ & PCR CONDITION \\
\hline Plasmodium sp. & $\begin{array}{l}\text { rPLU5 } \\
\text { rPLU6 }\end{array}$ & $\begin{array}{l}\text { CCTGTTGTTGCCTTAAACTTC } \\
\text { TTAAAATTGTTGCAGTTAAAACG }\end{array}$ & 1100 & $\begin{array}{l}\text { Initial denaturation at } 94^{\circ} \mathrm{C} \text { for } 3 \mathrm{~min}, 35 \\
\text { cycles of denaturation at } 94^{\circ} \mathrm{C} \text { for } 60 \text { seconds, } \\
\text { annealing at } 60^{\circ} \mathrm{C}\left(45^{\circ} \mathrm{C} \text { for P.ovale }\right) \text { for } 90 \\
\text { second, extension at } 72^{\circ} \mathrm{C} \text { for } 90 \text { second and } \\
\text { final extension for } 5 \text { minutes }\end{array}$ \\
\hline P. falciparum & $\begin{array}{l}\text { rFAL1 } \\
\text { rFAL2 }\end{array}$ & $\begin{array}{l}\text { TTAAACTGGTTTGGGAAAACC } \\
\text { AAATATATT } \\
\text { ACACAATGAACTCAATCATGA } \\
\text { CTACCCGTC }\end{array}$ & 205 & $\begin{array}{l}\text { Initial denaturation at } 94^{\circ} \mathrm{C} \text { for } 3 \mathrm{~min}, 35 \\
\text { cycles of denaturation at } 94^{\circ} \mathrm{C} \text { for } 60 \text { seconds, } \\
\text { annealing at } 55^{\circ} \mathrm{C} \text { for } 90 \text { second, extension at } \\
72^{\circ} \mathrm{C} \text { for } 90 \text { second and final extension for } 5 \\
\text { minutes }\end{array}$ \\
\hline P. vivax & $\begin{array}{l}\text { rVIV1 } \\
\text { rVIV2 }\end{array}$ & $\begin{array}{l}\text { CGCTTCTAGCTTAATCCACAT } \\
\text { AACTGATAC } \\
\text { ACTTCCAAGCCGAAGCAAAGA } \\
\text { AAGTCCTTA }\end{array}$ & 120 & $\begin{array}{l}\text { Initial denaturation at } 94^{\circ} \mathrm{C} \text { for } 3 \mathrm{~min}, 35 \\
\text { cycles of denaturation at } 94^{\circ} \mathrm{C} \text { for } 60 \text { seconds, } \\
\text { annealing at } 55^{\circ} \mathrm{C} \text { for } 90 \text { second, extension at } \\
72^{\circ} \mathrm{C} \text { for } 90 \text { second and final extension for } 5 \\
\text { minutes }\end{array}$ \\
\hline P.ovale & $\begin{array}{l}\text { rOVA1 } \\
\text { rOVAL2 }\end{array}$ & $\begin{array}{l}\text { ATCTCTTTTGCTATTTTTTAG } \\
\text { TATTGGAGA } \\
\text { GGAAAAGGACACATTAATTGT } \\
\text { ATCCTAGTG }\end{array}$ & 800 & $\begin{array}{l}\text { Initial denaturation at } 94^{\circ} \mathrm{C} \text { for } 3 \mathrm{~min}, 35 \\
\text { cycles of denaturation at } 94^{\circ} \mathrm{C} \text { for } 60 \text { seconds, } \\
\text { annealing at } 45^{\circ} \mathrm{C} \text { for } 90 \text { seconds, extension } \\
\text { at } 72^{\circ} \mathrm{C} \text { for } 90 \text { second and final extension for } \\
5 \text { minutes }\end{array}$ \\
\hline P. malariae & $\begin{array}{l}\text { rMAL1 } \\
\text { rMAL2 }\end{array}$ & $\begin{array}{l}\text { ATAACATAGTTGTACGTTAAG } \\
\text { AATAACCGC } \\
\text { AAAATTCCCATGCATAAAAAA } \\
\text { TTATACAAA }\end{array}$ & 144 & $\begin{array}{l}\text { Initial denaturation at } 94^{\circ} \mathrm{C} \text { for } 3 \mathrm{~min}, 35 \\
\text { cycles of denaturation at } 94^{\circ} \mathrm{C} \text { for } 60 \text { seconds, } \\
\text { annealing at } 55^{\circ} \mathrm{C} \text { for } 90 \text { second, extension at } \\
72^{\circ} \mathrm{C} \text { for } 90 \text { second and final extension for } 5 \\
\text { minutes }\end{array}$ \\
\hline
\end{tabular}

re-suspend the DNA at $65^{\circ} \mathrm{C}$ for 1 hour. The extracted DNA stored at $-86^{\circ} \mathrm{C}$ till further investigations.

\section{MOLECULAR DETECTION}

Nested PCR was carried out for detection and identification of Plasmodium species as described by Snounou et al. (1993). DNA samples were amplified by oligonucleotide primers obtained from Integrated DNA Technology (Belgium). These primers targeting the Plasmodium small subunit ribosomal RNA (ssRNA) genes. Primer pairs rPLU5 and rPLU6 used to detect Plasmodium genus in Primary amplification and species-specific primers rFAL1/rFAL2 ( $P$. falciparum), rVIV1/rVIV2 ( $P$. vivax), rOVAL1/rOVAL2 ( $P$. ovale) and rMAL1/rMAL2 (P. malariae) for nested PCR in 2 separated reaction.

In brief, primary and nested PCR were carried out in total $25 \mu \mathrm{l}$ reaction volume, each containing $12.5 \mu \mathrm{l}$ GoTag ${ }^{\circledR} \mathrm{G} 2$ green master mix ready to use from Promega and $25 \mu \mathrm{M}$ of each primer. Five $\mu \mathrm{l}$ of extracted DNA was used as a sample for the primary amplification and two $\mu l$ of the PCR product for the nested PCR. In each run, negative and positive controls were included. Thermal cycling was done in T100 thermal cycler (Bio-Rad, USA), PCR conditions are shown in Table (2). The PCR products of nested amplification were analyzed by gel electropho- resis (1.5 agaroses in Tris-Acetate-EDTA buffer) staining with ethidium bromide. The visualization was carried out using Gel Doc XR Imaging System (Bio-Rad).

\section{RESULTS}

A total of 138 samples re-diagnosed for Plasmodium species were Plasmodium positive by microscopy during 2011-2012, 92.8\% (128/138) of the samples diagnosed as $P$. falciparum and, 7.2\% (10/138) as $P$. vivax, no mixed infections were detected by the golden standard microscopic examination done by the best microscopists (details are shown in Table 3). Based on the nested PCR assay, $P$. falciparum (mono infection) has been detected in $86.23 \%(119 / 138)$ of the samples, $4.35 \%(6 / 138)$ were found P.vivax (mono infection) and 9.42\% (13/138) of the samples were positive to both $P$. falciparum and $P$. vivax (mixed infection) (Table 4 and Fig.2). No other Plasmodium species were detected by the microscopy and nested PCR.

\section{DISSCUTION}

Malaria transmission in Saudi Arabia occurs mainly in the southwest region in Asir and Jazan where the 


\begin{tabular}{|l|l|l|l|l|l|l|}
\hline Table 3. Distribution of Plasmodium species to the Governorates based on the microscopic diagnosis. \\
\hline Governorates & Samples no & +Ve P.falciparum & +Ve P.vivax & $\begin{array}{l}\text { +Ve Mixed } \\
\text { (P. vivax + P. } \\
\text { falciparum) }\end{array}$ & +Ve P. ovale & $\begin{array}{l}\text { +Ve } \\
\text { P. malariae }\end{array}$ \\
\hline Jazan & 22 & $15(68.2 \%)$ & $7(31.8 \%)$ & zero & zero & zero \\
\hline $\begin{array}{l}\text { Sabyah, Beash and } \\
\text { AL-Darb }\end{array}$ & 42 & $41(97.62 \%)$ & $1(2.38 \%)$ & zero & zero & zero \\
\hline $\begin{array}{l}\text { Samttah, AL-Ahad, } \\
\text { Towal and Khobah }\end{array}$ & 45 & $44(97.8 \%)$ & $1(2.22 \%)$ & zero & zero & zero \\
\hline $\begin{array}{l}\text { Abuareesh, Damad } \\
\text { and AL-Aridah }\end{array}$ & 29 & $28(96.6 \%)$ & $1(3.5 \%)$ & zero & zero & zero \\
\hline Total & 138 & $128(92.8 \%)$ & $10(7.2 \%)$ & zero & zero & zero \\
\hline
\end{tabular}

disease is endemic. Transmission of malaria is seasonal during winter where rain falls from September to February (Jamjoom et al., 2006). Introducing infection to nonendemic areas by pilgrims during Hajj and Umrah or through expatriate is a major threat to health authorities (Al-Tawfig and Memish, 2014). The quality of malaria diagnostic services would remain the main challenge in elimination and control in the region. Therefore, accurate and rapid diagnosis of Plasmodium infections is critical for proper malaria treatment. Giemsa-stained thick and thin films for malaria diagnosis remain the main conventional and classic method of microscopic examination for malaria in the region (Jamjoom et al., 2006). The method is highly subjective and laborious with low sensitivity for chronic and asymptomatic carriers (WHO, 2013).

Distinction between malaria parasite species is crucial in the clinical management of patients since the treatment depends mainly on the type of species that cause the infection (Mangold et al., 2005).In the present study, 138 samples were re-diagnosed by microscopy for Plasmodium species and found positive for two Plasmodium species (128 for $P$. falciparum [92.8\%] and 10 for $P$. vivax [7.2\%]). But no other plasmodium species or mixed infections were detected. The miss-diagnosing of the mixed infections with $P$. falciparum and $P$. vivax using microscopy may be attributed to cross-species immunity or competition at the level of host red blood cells (RBC) (Gupta et al., 2010). On other hand, the diagnosis by nested-PCR indicated 119 (86.23\%) and 6 (4.35\%) mono infection by $P$. falciparum and $P$. vivax, respectively. In addition, the method detected 13 (9.42\%) mixed infections with both $P$. falciparum and $P$. vivax.

These results suggest that where only microscopybased diagnostic methods are used, many cases of mixed Plasmodium species infections may be misdiagnosed. The findings of the present study contradict many studies in Saudi Arabia that revealed the dominancy of $P$. falciparum over other plasmodium species and the absence of mixed infections (e.g. Dawoud et al., 2008). The discrepancies between the results of the two methods are due to the fact that microscopists tend to misdiagnose mixed infections and identified them as either $P$. falciparum or $P$. vivax mono infections. Interestingly, the percentage of the mixed infections in the present investigation (9.42\%) is higher than previous reported from Sudan (4.2\%, Talha et al., 2014), Saudi Arabia (1.9\%, in Jazan region, Bin Dajem, 2015; and 2.4\%, Bashrawi et

\begin{tabular}{|l|l|l|l|l|l|l|}
\hline \multicolumn{2}{|l}{ Table 4. Distribution of Plasmodium species to the Governorates based on the nested-PCR. } \\
\hline Governorates & $\begin{array}{l}\text { Number of } \\
\text { samples }\end{array}$ & $\begin{array}{l}\text { +Ve } \\
\text { P. falciparum }\end{array}$ & +Ve P.vivax & $\begin{array}{l}\text { +Ve Mixed } \\
\text { (P. vivax and P. } \\
\text { falciparum) }\end{array}$ & $\begin{array}{l}\text { +Ve } \\
\text { P. ovale }\end{array}$ & $\begin{array}{l}\text { +Ve } \\
\text { P. malariae }\end{array}$ \\
\hline Jazan & 22 & $14(63.64 \%)$ & $5(22.73 \%)$ & $3(13.64)$ & zero & zero \\
\hline $\begin{array}{l}\text { Sabyah, Beash and } \\
\text { AL-Darb }\end{array}$ & 42 & $37(88.1 \%)$ & $1(2.4 \%)$ & $4(9.5)$ & zero & zero \\
\hline $\begin{array}{l}\text { Samttah, AL-Ahad, } \\
\text { Towal and Khobah }\end{array}$ & 45 & $40(88.9 \%)$ & Zero (0\%) & $5(11.1 \%)$ & zero & zero \\
\hline $\begin{array}{l}\text { Abuareesh, Damad } \\
\text { and AL-Aridah }\end{array}$ & 29 & $28(96.6 \%)$ & Zero (0\%) & $1(3.4 \%)$ & zero & zero \\
\hline Total & 138 & $119(86.23 \%)$ & $6(4.35 \%)$ & $13(9.42 \%)$ & zero & zero \\
\hline
\end{tabular}




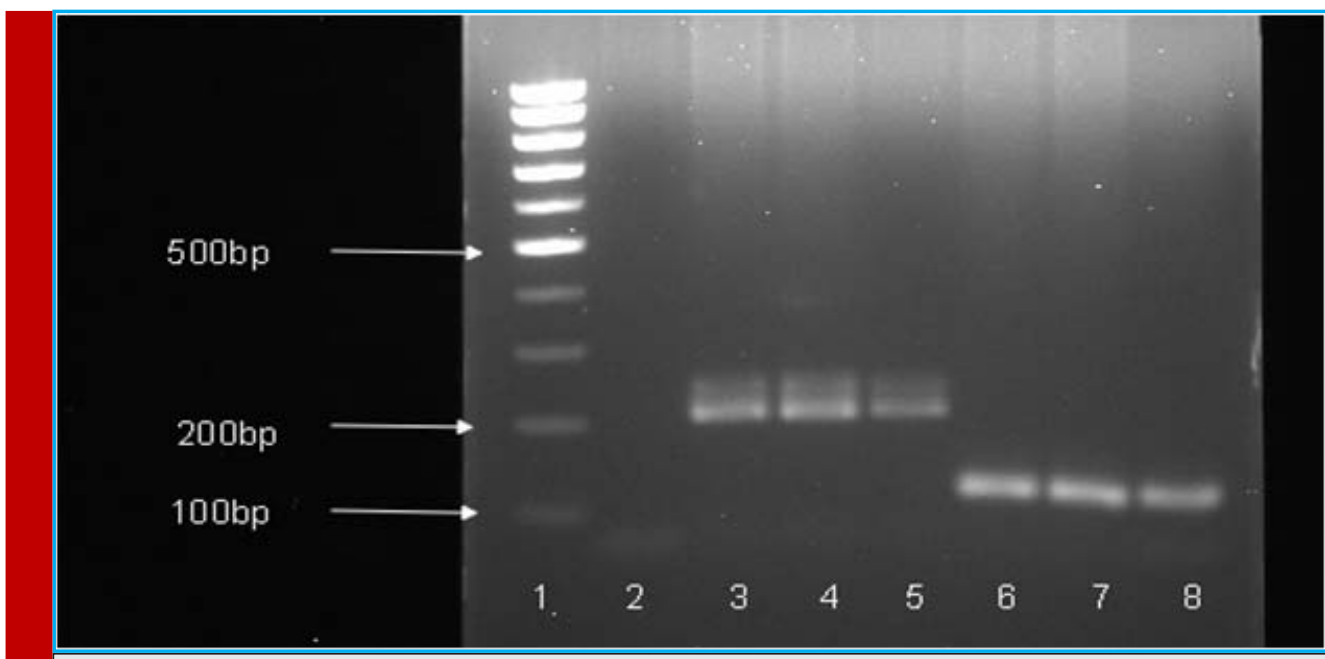

FIGURE 2. Agarose gel electrophoresis of nested-PCR by the Plasmodiumspecies-specific primers. Lane (1) 100bp DNA marker, lane (2) negative control, lane (3) positive P. falciparum control, lane $(4,5)$ positive $P$. falciparum samples $(205 \mathrm{bp})$, lane (6) positive $P$. vivax control and lane $(7,8)$ positive $P$. vivax samples (120bp).

al., 2002), Ethiopia (2.3\%, Mekonnen et al., 2014) and Afghanistan (6.5\%, Zakeri et al., 2010). However, it was less than reported from Bangladesh (27.5\%, Fuehrer et al., 2010), Brazil Amazon Regions (26.9\%, Lorenzetti et al., 2008), Pakistan (23.5\%, Zakeri et al., 2010), Iran (22\%, Zakeri et al., 2010) and Yemen (11.6\%, AlMekhlafi et al., 2010).

In mixed malaria infections, it is generally accepted that an antagonism exists between the Plasmodium species, where each species tends to dominate through the period of infection (Knowles et al., 1930; Coatney, 1968). This phenomenon could explain why mixed infections are difficult for microscopists to detect, particularly when the patient is sampled once (Snounou et $a l .$, 1993). It could be explained also by the reason that under microscopy and at early stage the size of $P$. vivax parasite resembles the size of $P$. falciparum. Additionally, fever induced by low parasiteima caused by $P$. vivax might hinder the pathogenic potential of $P$. falciparum (Yewhalaw et al., 2010). Therefore, the microscopists may frequently miss to differentiate between species especially when morphologic characteristics overlaps or in cases that parasite morphology has been altered by drug treatment, or in case of bad storage of the blood films and the sample processes (Talha et al., 2014).

The detection of mixed infections is highly important for both ascertaining the exact incidence of each species and its consequent transmission potential, and the successful clinical treatment. Moreover, the reduction of parasiteima in mixed infections due to suppression of one the species, changes the resulting morbidity and mortality (Snounou et al., 1993).In this study, we found that the nested-PCR techniques were able to detect the mixed infections of malaria, a result that leads to correct treatment and prompt diagnosis.

\section{CONCLUSION}

Considerable numbers of species mismatch and underreporting of mixed infections had been noticed in the diagnosis of malaria by microscopy alone in Jazan region. The nested-PCR used in the present study is reliable to detect precisely the type of Plasmodium species and any Plasmodium mixed-infections. It is valuable as a confirmatory test and should be considered by reference laboratories in the region and other malaria endemic regions of the Kingdom of Saudi Arabia. False diagnosis of plasmodium species along with under reporting of mixed infections need special attention and should be improved for accurate and reliable malaria diagnosis and malaria control and/or elimination efforts. The molecular techniques are thought to be not practical in rural areas for examination of $P$. falciparum and/or $P$. vivax, yet they could be used in epidemiological surveillance and control or/and elimination programs.

\section{REFERENCES}

Al-Mekhlafi, A. MQ, Mohammed AK Mahdy, Ahmed Azazy A, Mun Yik Fong (2010). Molecular epidemiology of Plasmodium species prevalent in Yemen based on $18 \mathrm{~s}$ rRNA Parasites and Vectors. 2010; 3:110.

Al-Sheik, A. A. (2011). Larval habitat, ecology, seasonal abundance and vectorial role in malaria transmission of Anopheles arabiensis in Jazan Region of Saudi Arabia. Journal of the Egyptian Society of Parasitology, 41 (3): pp. 615-634. 
Al-Tawfiq, JA and Memish, JA, 2014: Mass gathering medicine: 2014 Hajj and Umra preparation as a leading example. Int J Infect Dis. 2014; 27: 26-31.

Askling, H. H., Nilsson, J., Tegnell, A., Janzon, R., and Ekdahl, K. (2005). Malaria risk in travelers. Emerg Infect Dis, 11 (3): pp. 436-41.

Bashawri, L. AM, Ahmed A Mandil, Ahmed A Bahnassy, Mirghani A Ahmed (2002). Malaria: Hematological Aspects Annals of Saudi Medicine. 2002; 22:5-6.

Bin Dajem, S. M. (2015) Molecular investigation of mixed malaria infections in Southwest Saudi Arabia. Saudi Medical Journal, Vol. 36, No 2 (2015).

CDC (2016). Malaria parasites [Online]. Available from: https:// www.cdc.gov/malaria/about/biology/parasites.html (Accessed 4/2/2017).

Coatney, G.R. (1968) Simian malaria in man: facts, implications and predictions. Am. J. Trop. Mcd. l-lyg. 17. 147155.

Cowman, A. F., and Crabb, B. S. (2006). Invasion of red blood cells by malaria parasites. Cell, 124 (4):

pp. 755-766.

Dawoud HA, Ageely HM, Heiba AA. (2008). Evaluation of a real-time polymerase chain reaction assay for the diagnosis of malaria in patients from Jazan area, Saudi Arabia. J Egypt Soc Parasitol 2008; 38: 339-350.

El Hassan, I. M., Sahly, A., Alzahrani, M. H., Alhakeem, R. F., Alhelal, M., Alhogail, A.and Atas, M. (2015). Progress toward malaria elimination in Jazan Province, Kingdom of Saudi Arabia: 2000-2014. Malaria Journal, 14 (1): pp. 1-10.

Fuehrer H, Fuehrer H, Peter Starzengruber, Paul Swoboda, Wasif Ali Khan , Julia Matt, Benedikt Ley, et al (2010). Indigenous Plasmodium ovale Malaria in Bangladesh. Am J Trop Med. Hyg. 2010; 83(1):75-78.

Gupta B, Gupta P, Sharma A, Singh V, Dash AP, Das A (2010). High proportion of mixed-species Plasmodium infections in India revealed by PCR diagnostic assay. Trop Med Int Health 2010; 15: 819-824.

Hänscheid, T. (2003). Current strategies to avoid misdiagnosis of malaria.Clinical Microbiology and Infection, 9 (6): pp. 497504.

Jamjoom MB, Azhar EA, Tonkol AK, Al-Harthi SA, Ashankyty IM (2006). Detection of malaria in Saudi Arabia by real-time PCR. J Egypt Soc Parasitol. 2006 Dec; 36(3):737-48.

Jerrard, D. A., Broder, J. S., Hanna, J. R., Colletti, J. E., Grundmann, K. A., Geroff, A. J., and Mattu, A. (2002). Malaria: a rising incidence in the United States. The Journal of emergency medicine, 23 (1): pp. 23-33.

Johnston, S. P., Pieniazek, N. J., Xayavong, M. V., Slemenda, S. B., Wilkins, P. P., and da Silva, A. J. (2006). PCR as a confirmatory technique for laboratory diagnosis of malaria. Journal of clinical microbiology, 44 (3): pp. 1087-1089.

Knowles, R., White, R.S. and Das Gupta. B.M. (1930) Studies in the parasitology of malaria. Indian Medical Research $\backslash 1 \mathrm{cmoirs}$ 18 , I 4)6.
Lee, M. A., Tan, C. H., Aw, L. T., Tang, C. S., Singh, M., Lee, S.H., and Yap, E. P. (2002). Real-time fluorescence-based PCR for detection of malaria parasites. Journal of clinical microbiology, 40 (11): pp. 4343-4345.

Lorenzetti A, Patrıcia Aparecida Fornazari, Ana Carolina B, Roberta de Souza Rodrigues Penhalbel, Erika Fugikaha, Claudia RB, et al (2008). Mixed Plasmodium falciparum infections and its clinical implications in four areas of the Brazilian Amazon region. Acta Trop. 2008;107(1):8-12.

Mangold, K. A., Manson, R. U., Koay, E. S., Stephens, L., Regner, M., Thomson, R. B., and Kaul,

K. L. (2005). Real-time PCR for detection and identification of Plasmodium spp. Journal of clinical microbiology, 43 (5): pp. 2435-2440.

McNamara, D. T., Thomson, J. M., Kasehagen, L. J., and Zimmerman, P. A.(2004). Development of a multiplex PCR-ligase detection reaction assay for diagnosis of infection by the four parasite species causing malaria in humans. Journal of clinical microbiology, 42 (6): pp. 2403-2410.

Mekonnen, S.K., Abraham Aseffa, Girmay Medhin, Nega Berhe and Thirumalaisamy P Velavan (2014). Re-evaluation of microscopy confirmed Plasmodium falciparum and Plasmodium vivax malaria by nested PCR detection in southern Ethiopia. Malaria Journal. 2014; 13:48.

Mok, S., Ashley, E. A., Ferreira, P. E., Zhu, L., Lin, Z., Yeo, T., and Nguon, C. (2015). Population transcriptomics of human malaria parasites reveals the mechanism of artemisinin resistance. Science, 347 (6220): pp. 431-435.

Morassin, B., Fabre, R., Berry, A., and Magnaval, J. F. (2002). One year's experience with the polymerase chain reaction as a routine method for the diagnosis of imported malaria. The American journal of tropical medicine and hygiene, 66 (5): pp. 503-508.

Patsoula, E., Spanakos, G., Sofianatou, D., Parara, M., and Vakalis, N. C. (2003). A single-step, PCR-based method for the detection and differentiation of Plasmodium vivax and P. falciparum. Annals of Tropical Medicine \& Parasitology, 97 (1): pp. 15-21.

Perandin, F., Manca, N., Calderaro, A., Piccolo, G., Galati, L., Ricci, L., and Chezzi, C. (2004)

Development of a real-time PCR assay for detection Plasmodium falciparum, Plasmodium vivax, and Plasmodium ovale for routine clinical diagnosis. Journal of clinical microbiology, 42 (3): pp. 1214-1219.

Sebai, Z. (1988). Malaria in Saudi Arabia. Trop. Doctor (18): pp. 183-88.

Snounou, G. S., S. Viriyakosol, X. P. Zhu, W. Jarra, L. Pinheiro, V. E. do Rosario, S. Thaithong, and K. N. Brown. 1993. High sensitivity of detection of human malaria parasites by the use of nested polymerase chain reaction.

Talha A, Pirahmadi S, Elgaily EM et al. (2014). Low prevalence of Plasmodium vivax - Plasmodium falciparum mixedinfection in patients from central and eastern part of Sudan: Implication for case management in Sudan. Int $\mathrm{J}$ of Trop Dis Health 2014:4; 887-95. 
Van Hong, N., van den Eede, P., Van Overmeir, C., Vythilingham, I., Rosanas-Urgell, A., Thanh, P. V., and Erhart, A. (2013). A modified semi-nested multiplex malaria PCR (SnM-PCR) for the identification of the five human Plasmodium species occurring in Southeast Asia. The American journal of tropical medicine and hygiene, 89 (4): pp. 721-723.

WHO, 2013: World Malaria Report 2013. Geneva: WHO Press.

WHO. (2014). World malaria report 2013. Geneva: World Health Organization; 2014. http://www.who.int/malaria/publications/ world_malaria_report_2013/en/.

World Health Organization (2016). Fact Sheet: World malaria report 2015. http://www.who.int/malaria/media/world-malariareport-2015/en. /
Yewhalaw D, Kassahun W, Woldemichael K, Tushune K, Sudaker M, Kaba D, Duchateau L, Van Bortel W, Speybroeck N (2010).The influence of the Gilgel-Gibe hydroelectric dam in Ethiopia on caregivers' knowledge, perceptions and healthseeking behaviour towards childhood malaria. Malar J. 2010, 9: 47-10.1186/1475-2875-9-47.

Zahar, A. (1985). Vector Bionomics in Epidemiology and Control of Malaria Part I, WHO Geneva.

Zakeri S, Qutbuddin Kakar, Faezeh Ghasemi, Ahmad Raeisi, Waqar Butt, Navid Dinparast Djadid et al (2010). Detection of mixed infection of $P$. falciparum and $P$. vivax infection by nested PCR in Pakistan, Iran and Afaganistan, Indian J of Med Res 132. 2010;31:35 